\title{
Analysis of financial development and industrial structure transformation
}

\author{
Shuwei Harold Sun ${ }^{1}$, Allen Wang ${ }^{2 *}$, Huan $\mathrm{Yu}^{3}$ \\ ${ }^{1}$ Beijing Silverlight Investment Management Co.ltd., Floor 15, Fortune Financial Center, NO. 7, Dong Sanhuan Road, Chaoyang District \\ 2 Beijing Silverlight Investment Management Co.ltd., Floor 15, Fortune Financial Center, NO. 7, Dong Sanhuan Road, Chaoyang District \\ ${ }^{3}$ Beijing Silverlight Investment Management Co.ltd. Floor 15, Fortune Financial Center, NO. 7, Dong Sanhuan Road, Chaoyang District \\ ${ }^{*}$ Corresponding author: Allen Wang
}

\begin{abstract}
This paper uses the relevant data from 2008 to 2017 to construct a multiple linear regression equation, and uses the generalized moment estimation model to explore the impact of financial development on industrial structure adjustment from the perspective of financial scale and efficiency. The results show that financial efficiency can promote the rationalization and upgrading of industrial structure, but the impact of financial scale on industrial structure is two-sided. Increasing financial scale can increase the amount of industrial financing and accelerate the process of industrial structure upgrading. However, blindly increasing the supply of loans will lead to the birth of bad investment, thus failing to promote the rationalization of industrial structure. Based on this, this paper puts forward some policy suggestions, such as promoting the diversified development of the financial industry, improving the imbalance of financial development in various provinces, promoting the reasonable investment structure and the development of high-tech industry, and giving full play to the role of the government.
\end{abstract}

\section{Introduction}

At present, China's economic development has entered the new normal, the economic growth rate has gradually slowed down, and the pressure of industrial structure transformation and upgrading has become increasingly prominent. Under the new economic situation, it is particularly important to fundamentally change the extensive economic development mode in the past, accelerate the pace of industrial structure optimization, and enhance the core competitiveness of the industry. As the core component of modern economic development, finance plays a guiding role in the speed, efficiency and direction of industrial development, and is an important factor affecting the optimization and upgrading of industrial structure. With the optimization of financial structure and the improvement of financial efficiency, giving full play to the "foundation" role of Finance in the process of optimization and upgrading of industrial structure. Taking financial institutions as the bridge and financial resources as the link, promoting the industrial structure to be advanced and efficient has become an important measure for China's economy to maintain medium and high-speed growth in the new period.

\section{Research background and theoretical basis}

Scholars at home and abroad have done a lot of research on this subject. Financial capital will provide a lot of capital flow for the whole market, which can not only promote economic development, but also affect the adjustment of industrial structure. Whether a country's financial structure is bank led or market-oriented, the most important thing is to improve the function of financial system and legal system. Only by strengthening the legal protection of external investors can we achieve the purpose of promoting the development of emerging industries and optimizing the industrial structure. With the improvement of China's financial environment and the rapid development of the tertiary industry, Chinese scholars have gradually increased their research on this topic. The relationship between financial development and industrial structure adjustment is obvious. When the financial development is insufficient, it will hinder the economic development and the upgrading of industrial structure. When the industrial structure adjustment is hindered, the financial development will also decline. Finance can promote the upgrading and rationalization of industrial structure at the same time. However, the effects of these two kinds of promoting effects are asymmetric The development of industrial structure is uneven, which weakens the 
optimization process of industrial structure.

The contribution of high-level industries to economic growth is higher. Promoting the development of high-level industries is an effective measure to promote the stable economic growth of developing countries. The reason why we attach importance to the role of Finance in the adjustment of industrial structure is precisely because it controls the most important factor of production capital. In the development process of the financial industry, the industrial structure can be affected by expanding the financial scale, that is, increasing the financing channels and the amount of financing. Enterprises have more funds for production or R \& D innovation, and more production factors can be used. Financial development not only refers to the increase of capital quantity. When the increase of capital quantity is not used reasonably, the development of financial industry is not comprehensive. Therefore, we should pay attention to the allocation and flow of financial resources in the actual production process, that is, the efficiency of financial development. The efficiency of financial development refers to the utilization rate of capital in circulation among industries, which shows the allocation of resources among different industries. The financial system can affect the development of enterprises by this way of resource allocation. Due to the profit-seeking nature of financial institutions, capital will flow from backward enterprises with low production capacity to innovative technology-based enterprises with high efficiency, so as to promote the development of emerging high-quality industries. This paper measures the impact of financial structure on financial structure from two aspects.

\section{The function mechanism of financial development and industrial structure transformation}

As far as China's overall financial situation is concerned, because China is a developing country, it also determines that the most important financial industry is banks, and banks occupy a very important position in China's economic development. Because the bank is the main body of the financial industry, so for the market financing of our country, the role of the bank is beyond the stock or securities and other financial industries. Market financing is mainly divided into direct financing and indirect financing, but in the field of financial investment, the role of direct financing is lower than that of indirect financing. With the continuous development of banks and the expansion of market scale, the financial structure of private credit is also gradually increasing. Therefore, more and more enterprises begin to obtain credit through private financial institutions, which to a certain extent also expands the industrial structure and plays a promoting role in economic development. Because banks are the main part of the development of the financial industry, in the process of upgrading the industrial structure, the role of banks should exceed the impact of the market. At present, in view of the current situation of China's economic development, we still need to play the role of banks in the economic structure, but we need to pay attention to the fact that with the continuous development of the economy, the industrial structure should be constantly improved, and the overall optimization of the financial industry should be emphasized.

\subsection{Financing behavior in the development of market economy}

The financing form in the development of market economy is an important form of financial development in the upgrading of China's structural industry. The current financing behavior is mainly divided into indirect financing in the bank credit market and direct financing in the capital market However, it has a positive role in promoting the upgrading of China's industrial structure.

\subsubsection{Bank credit market}

Bank credit market is mainly based on China's relevant macro-control policies, and can be consistent with the planning and development of the actual industry. A form of credit rationing and loan subsidy selected by this way plays an important role in the upgrading process of China's industrial structure.

\subsection{2 capital market}

Capital market capital market is mainly based on the role of market orientation. In order to adapt to the development standards of industrial structure, it is necessary to ensure the consistency with the direction of industrial structure adjustment. Only in this way can the resources in the capital market be effectively used, so as to promote its rapid development.

\subsection{The upgrading of industrial structure can meet the requirements of financial development}

Since the reform of China, both the economic level and the development of science and technology have been effectively improved, especially the optimization of the traditional industrial structure and the continuous emergence of new industries, which will certainly bring direct impact on the current financial development, especially in the financial development requirements will play a promoting role. In order to promote the rapid upgrading of China's industrial structure, the mode of financial development must be changed to meet the needs of the current industrial structure upgrading. Moreover, the financial industry will also present the characteristics of diversification and modernization, laying the foundation for improving financial services and creating better conditions for the transformation and upgrading of industrial structure. In addition, in the process of upgrading China's industrial structure, in order to adapt to the development of industrial structure, 
financial development must innovate its own supply channels and investment and financing methods.

\section{Empirical analysis of financial development on industrial structure transformation}

\subsection{Variable selection and description}

According to different research contents and emphases,

Table 1 Variable definition and description

\begin{tabular}{c|c|c}
\hline Variable & Symbol & Definition \\
\hline Industrial upgrading & Ts & $\begin{array}{c}\text { Output value of tertiary industry/ Output } \\
\text { value of secondary industry }\end{array}$ \\
\hline Industrial rationalization & E & $\begin{array}{c}\text { Rationalization index of industrial } \\
\text { structure }\end{array}$ \\
\hline Financial efficiency & Ldr & $\begin{array}{c}\text { Annual loan balance of financial } \\
\text { institutions/ Annual deposit balance of } \\
\text { financial institutions }\end{array}$ \\
\hline Financial scale & Fir & $\begin{array}{c}\text { Total annual deposit and loan balance of } \\
\text { financial institutions/ Regional GDP }\end{array}$ \\
\hline The level of government expenditure & Gov & $\begin{array}{c}\text { Government expenditure/ Regional GDP } \\
\text { Investment level of fixed assets }\end{array}$ \\
\hline Degree of opening up & Inv & $\begin{array}{c}\text { Total investment in fixed assets/ Regional } \\
\text { GDP }\end{array}$ \\
\hline
\end{tabular}

Among them, the selection of industrial structure rationalization index, the introduction of Theil index and optimization, considering the structural weight of each industry, this paper thinks that this index can more accurately reflect the current situation of China's industrial structure rationalization. different scholars choose different control variables. Since financial assets are still concentrated in the hands of financial institutions represented by banks, and the most important financial instruments of financial institutions are deposits and loans, the selection of indicators for financial development in this paper is shown in Table 1.

$$
\mathrm{E}=\sum_{i=1}^{n}\left(\frac{Y_{i}}{Y}\right) \operatorname{Ln}\left(\frac{Y_{i} / L_{i}}{Y / L}\right) \quad \operatorname{Ln}=1|2| 3 Y
$$

Among them, $\mathrm{E}$ is the rationalization level of the industry, $\mathrm{Y}$ is the output value of the three industries, $\mathrm{L}$ is the employment number corresponding to the three industries, $\mathrm{i}$ is the industry, and $\mathrm{nl-3}$ is the three industries respectively.

Table 2 descriptive statistics

\begin{tabular}{c|cccccc}
\hline VarName & Obs & Mean & SD & Min & Median & Max \\
\hline Ts & 750 & 0.964 & 0.455 & 0.517 & 0.86 & 4.24 \\
E & 750 & 0.239 & 0.145 & 0.012 & 0.22 & 0.87 \\
Fir & 750 & 2.482 & 0.957 & 1.15 & 2.36 & 7.57 \\
Ldr & 750 & 0.829 & 0.213 & 0.401 & 0.79 & 1.89 \\
Gov & 750 & 0.173 & 0.090 & 0.049 & 0.15 & 0.63 \\
Open & 750 & 0.153 & 0.242 & 0.004 & 0.05 & 1.63 \\
Inv & 750 & 0.532 & 0.244 & 0.192 & 0.46 & 1.48 \\
\hline
\end{tabular}




\subsection{Establish measurement model}

The sample interval of this paper is 2008-2017, and the total number of provinces is 30 (except Tibet). According to the actual situation in China, the measurement model is established as follows:

$$
\text { Indus }_{i t}=\beta_{0}+\gamma \operatorname{Indus}_{i, t-1}+\beta_{1} \text { Fin }_{i t}+\theta X_{i t}+\varepsilon_{i t}+\mu_{i}
$$

Among them, Indus $s_{i t}$ stands for the advanced industrial structure $\left(\mathrm{Ts}_{\mathrm{it}}\right)$ and rationalization of industrial structure $\left(E_{i t}\right)$, Finit measures the degree of financial development and represents financial scale (FIR) and financial efficiency (Ldr). $X_{i t}$ is the control variable vector, specifically including fixed asset investment (Inv), foreign capital utilization level (Fdi) and opening degree (Open). $\mu_{\mathrm{i}}$ is the residual term, which is the unobservable heterogeneity. These two constitute a compound disturbance term, and $\theta$ is the parameter to be estimated.

The adjustment of industrial structure has the characteristics of time persistence. The adjustment of industrial structure in a region in the current year will be affected by the adjustment of industrial structure in the previous year. Therefore, this paper introduces the lag period of dependent variable as an independent variable and adds it to the regression model to study the influence of the past industrial structure on the present The introduced variable may have autocorrelation with the residual term of the model. In order to avoid the bias of the regression results and lead to the inconsistency of coefficient estimation, the dynamic panel model is used to solve this problem.

\subsection{Analysis of empirical results}

Table 3 shows the GMM regression results of dynamic model (1). In this regression, a dummy variable is added to divide 30 provinces into developed areas and underdeveloped areas for comparative analysis. 1 represents the developed regions including Beijing, Tianjin, Liaoning, Shanghai, Jiangsu, Shandong, Guangdong and Zhejiang, and 0 represents the underdeveloped areas including the other 22 provinces. Among them, $*$, **, and *** represent significance levels of $0.1,0.05$ and 0.01 , respectively. The number below the partial regression coefficient refers to $t$ value. Hansen test value $\mathrm{p}$ value is greater than 0.1 , through the test, verify the effectiveness of tool variables. The AR (2) test shows that there is no second-order autocorrelation in the residual term. The lag coefficient of the two dependent variables is positive, which is significant at the level of 0.01 , so the regression is effective. Column (1) and column (4) of this regression are the results of the regression of the whole sample, and columns (2) (3) and (5) (6) are the regression of the undeveloped regions and the developed regions respectively, which are used to compare and analyze the impact of financial development in different regions on the adjustment of industrial structure.

Table 3 The regression result of the industrial structure's advancement and rationalization

\begin{tabular}{|c|c|c|c|c|c|c|}
\hline & $\begin{array}{l}\text { (1) } \\
T s\end{array}$ & $\begin{array}{c}\text { (2) } \\
\text { Type }=0\end{array}$ & $\begin{array}{c}\text { (3) } \\
\text { Type }=1\end{array}$ & $\begin{array}{l}(4) \\
E\end{array}$ & $\begin{array}{c}\text { (5) } \\
\text { Type }=0\end{array}$ & $\begin{array}{c}\text { (6) } \\
\text { Type }=1\end{array}$ \\
\hline L. E & & & & $\begin{array}{c}0.5671 * * * \\
(26.204)\end{array}$ & $\begin{array}{c}0.5726^{* * * *} \\
(20.612)\end{array}$ & $\begin{array}{c}0.4915 * * \\
(2.036)\end{array}$ \\
\hline Fir & $\begin{array}{c}0.0606^{* * *} \\
(13.281)\end{array}$ & $\begin{array}{c}0.1017 * * * \\
(3.522)\end{array}$ & $\begin{array}{l}-0.0696 \\
(-0.727)\end{array}$ & $\begin{array}{c}0.0204 * * * \\
(5.642)\end{array}$ & $\begin{array}{c}0.0377 * * * \\
(8.768)\end{array}$ & $\begin{array}{c}0.0282 * * \\
(2.186)\end{array}$ \\
\hline Ldr & $\begin{array}{c}0.1853^{* * *} \\
\quad(8.626)\end{array}$ & $\begin{array}{c}0.2379 * * * \\
(22.709)\end{array}$ & $\begin{array}{c}0.3714 * \\
(1.666)\end{array}$ & $\begin{array}{c}-0.0873 * * * \\
(-9.820)\end{array}$ & $\begin{array}{c}-0.1138^{* * *} \\
(-12.083)\end{array}$ & $\begin{array}{l}-0.0360 \\
(-0.461)\end{array}$ \\
\hline Gov & $\begin{array}{c}0.2477 * * \\
(2.442)\end{array}$ & $\begin{array}{l}0.0203 \\
(0.233)\end{array}$ & $\begin{array}{c}8.7850 * * \\
(2.452)\end{array}$ & $\begin{array}{c}0.2012 * * * \\
\quad(3.288)\end{array}$ & $\begin{array}{c}0.2176^{* * *} \\
(3.578)\end{array}$ & $\begin{array}{c}-0.6759^{*} \\
(-1.823)\end{array}$ \\
\hline Open & $\begin{array}{c}0.6395 * * * \\
(-19.996)\end{array}$ & $\begin{array}{l}0.1464 \\
(1.089)\end{array}$ & $\begin{array}{l}-0.3738 \\
(-1.627)\end{array}$ & $\begin{array}{l}0.0042 \\
(0.413)\end{array}$ & $\begin{array}{l}-0.1976 \\
(-1.102)\end{array}$ & $\begin{array}{l}-0.0260 \\
(-0.670)\end{array}$ \\
\hline Inv & $\begin{array}{c}0.1495^{* * *} \\
(6.099)\end{array}$ & $\begin{array}{l}0.0177 \\
(0.308)\end{array}$ & $\begin{array}{l}-0.8738 \\
(-1.427)\end{array}$ & $\begin{array}{c}-0.2170 * * * \\
(-17.534)\end{array}$ & $\begin{array}{c}-0.1657 * * * \\
(-10.853)\end{array}$ & $\begin{array}{l}-0.0688 \\
(-1.019)\end{array}$ \\
\hline L. Ts & $\begin{array}{c}0.7401 * * * \\
(42.881)\end{array}$ & $\begin{array}{c}0.7854 * * * \\
(13.212)\end{array}$ & $\begin{array}{l}0.3002 \\
(1.107)\end{array}$ & & & \\
\hline AR1 & $-2.95(0.003)$ & $-2.71(0.007)$ & $-1.10(0.270)$ & $-2.77(0.006)$ & $-2.74(0.006)$ & $-0.85(0.396)$ \\
\hline AR2 & $-1.03(0.303)$ & $-0.60(0.546)$ & $-0.35(0.728)$ & $-0.05(0.958)$ & $-0.52(0.605)$ & $-1.20(0.229)$ \\
\hline Hansen & $29.02(0.901)$ & $19.98(0.997)$ & $1.42(1.000)$ & $26.95(0.928)$ & $19.99(0.995)$ & $1.10(1.000)$ \\
\hline
\end{tabular}


From the regression results, we can see that the partial regression coefficients of lag variables with dependent variables are the maximum of the partial regression coefficients of the regression, and the significant positive impact at the level of 0.01 indicates that there is a large inertia in the industrial structure, and the upgrading of the industrial structure in the previous year will have a greater impact on the industrial structure of the next year, It shows that the upgrading of industrial structure is a long-term, dynamic and continuous process, and the structural adjustment is not completed in a short time. However, if the scale of the financial structure is different from that of the financial structure, it will only increase the scale of the financial industry The rationalization and upgrading of industrial structure and employment structure are also hindered. For China's non developed regions, the adjustment of financial structure plays a more significant role in promoting the development of China's non developed regions. Most of the government's fiscal expenditure goes to the service industry, which promotes the development of the industrial structure. However, because the overall economic level of many provinces and cities in China is not high enough, in order to improve people's livelihood, many transfer payments of the state are invested in this part, and a large number of funds flow into many inefficient or even loss making departments. Although it is significant from the national point of view, it is not conducive to the rational development of industrial structure.

\subsection{Model checking}

On the one hand, financial density reflects the results of resource allocation of financial service providers such as banks; on the other hand, it reflects the quality of financial services that enterprises and other financial demanders can get. Using the method of Li Jianjun and Han Ke for reference, this paper uses the dens index of bank loans to express the financial density, and the ratio of bank loans to the area of each province, which is used as a substitution variable for financial efficiency in the return of industrial upgrading. Based on the methods of $\mathrm{Hu}$ Qiuling and Liu Wei, the ratio of the sum of the added value of the secondary industry and the tertiary industry to GDP is used to measure the industrial rationalization $\mathrm{E} 1$.

Table 4 The robustness test of industrial upgrading and rationalization

\begin{tabular}{|c|c|c|c|c|}
\hline & $\begin{array}{l}(1) \\
T s\end{array}$ & $\begin{array}{l}(2) \\
T s\end{array}$ & $\begin{array}{l}(3) \\
E\end{array}$ & $\begin{array}{l}\text { (4) } \\
E 1\end{array}$ \\
\hline L. E & & & $\begin{array}{c}0.5672 * * * \\
(26.204)\end{array}$ & \\
\hline Fir & $\begin{array}{c}0.0606^{* * *} \\
(13.281)\end{array}$ & $\begin{array}{c}0.0971 * * * \\
(12.392)\end{array}$ & $\begin{array}{c}0.0204 * * * \\
(5.642)\end{array}$ & $\begin{array}{c}0.0150 * * * \\
(14.551)\end{array}$ \\
\hline Ldr & $\begin{array}{c}0.1853^{* * *} \\
(8.626)\end{array}$ & & $\begin{array}{l}-0.0873 \\
(-9.820)\end{array}$ & $\begin{array}{c}-0.0563 * * * \\
(-9.782)\end{array}$ \\
\hline Gov & $\begin{array}{c}0.2477 * * * \\
(2.442)\end{array}$ & $\begin{array}{c}-0.6273 * * * \\
(-9.343)\end{array}$ & $\begin{array}{c}0.2012 * * * \\
(3.288)\end{array}$ & $\begin{array}{c}0.0307 * * * \\
(2.480)\end{array}$ \\
\hline Open & $\begin{array}{c}-0.6395 * * * \\
(-19.996)\end{array}$ & $\begin{array}{c}-0.7601 * * * \\
(-20.416)\end{array}$ & $\begin{array}{l}0.0042 \\
(0.413)\end{array}$ & $\begin{array}{l}-0.0073 \\
(-1.248)\end{array}$ \\
\hline Inv & $\begin{array}{c}0.1495^{* * *} \\
(6.099)\end{array}$ & $\begin{array}{l}-0,0097 \\
(-0.374)\end{array}$ & $\begin{array}{c}-0.2170 * * * \\
(-17.534)\end{array}$ & $\begin{array}{c}-0.0255^{* * *} \\
(-16.550)\end{array}$ \\
\hline L. Ts & $\begin{array}{c}0.7401 * * * \\
(42.881)\end{array}$ & $\begin{array}{c}0.5844 * * * \\
(44.131)\end{array}$ & & \\
\hline Dens & & $\begin{array}{c}0.1770^{* * *} \\
(8.409)\end{array}$ & & $\begin{array}{c}0.7699 * * * \\
(28.909)\end{array}$ \\
\hline L. E1 & & & & $\begin{array}{c}0.7699 * * * \\
(28.909)\end{array}$ \\
\hline $\mathrm{N}$ & 680 & 680 & 680 & 680 \\
\hline Wald & $9570.87(0.000)$ & $37345.42(0.000)$ & $4487.06(0.000)$ & $65803.86(0.000)$ \\
\hline AR1 & $-2.95(0.003)$ & $-2.18(0.029)$ & $-2.77(0.006)$ & $-2.10(0.036)$ \\
\hline AR2 & $-1.03(0.303)$ & $-0.74(0.461)$ & $-0.05(0.958)$ & $1.51(0.131)$ \\
\hline Hansen & $29.02(0.901)$ & $28.21(0.919)$ & $26.95(0.928)$ & $27.14(0.924)$ \\
\hline
\end{tabular}


Column (1) represents the original regression, column (2) is the regression result after replacing variables, and Wald value represents that the model is significant. It can be seen from table 4 that whether the ratio of deposit to loan or the density of bank loans is used, the symbol of financial development efficiency coefficient, which is the core explanatory variable in this paper, is consistent and significant with the original regression results. The regression results of E1 and $\mathrm{E}$ are consistent and significant after using the substitution variable E1 of rationalization of industrial structure, which indicates that the two regression groups have passed the robustness test.

\section{Conclusion}

This paper uses the relevant data from 2008 to 2017 to construct multiple linear regression equation, and uses the generalized moment estimation model to explore the impact of financial development on industrial structure adjustment from the perspective of financial scale and efficiency. Based on the analysis of this paper, four suggestions are put forward: first, local governments should formulate financial development strategies according to local conditions, improve the imbalance of financial development in each province, and promote the rational development of investment structure; second, encourage the development of modern agricultural industry and promote the development of high-tech industry, Third, we should give full play to the role of the government, reduce the interference in credit, and let financial institutions allocate capital according to the law of the market; fourth, actively promote the development of securities and insurance industries, establish a sound market mechanism, and encourage the diversified development of the financial industry.

\section{Acknowledgment}

This study was supported by Research on Beijing Silverlight Investment Management Co.ltd.

\section{References}

1. Hongyu P, Yaru L. Housing Price, Financial Development and Industrial Structure Upgrading in Manufacturing Industry-Experience Analysis Based on Dynamic Panel[J].The Theory and Practice of Finance and Economics, 2019.

2. Jing D, Yue G. Financial Development and Industrial Structure Upgrading: the Perspective of Endogenous Technological Change[J].ence \& Technology Progress and Policy, 2019.

3. Feng L, Jun-Li C. Local Government Behavior, Financial Development and Industrial Structure Upgrading_-An Empirical Analysis Based on the Inter-provincial Dynamic Panel Data[J]. East China Economic Management, 2018.

4. Feng, Liang, and C. Jun-Li. "Local Government
Behavior, Financial Development and Industrial Structure Upgrading__An Empirical Analysis Based on the Inter-provincial Dynamic Panel Data." East China Economic Management (2018).

5. Linhan L, Weimin T. Environmental Regulation, Financial Development and Industrial Structure Upgrading[J]. Exploration of Financial Theory,2018.

6. $\mathrm{Xu} \mathrm{L,} \mathrm{Tan} \mathrm{J.} \mathrm{Financial} \mathrm{development,} \mathrm{industrial}$ structure and natural resource utilization efficiency in China[J]. Resources Policy, 2020,66.

7. Yanzhi T, Jichun P. Financial Development, Industrial Structure Upgrading and Inclusive Growth:Analysis Based on the People's Livelihood and Development[J]. Journal of Social ence of Hunan Normal University, 2019.

8. Wenbo W, Economics S O, University N. Financial Development, Technological Innovation and Industrial Structure Upgrading_-An Empirical Analysis based on Provincial Data[J]. Research of Finance and Education, 2019.

9. Jian-Guo Z, Zhi-Peng W, Branch H C. Research on the Impact of Financial Development in Resource-based Regions on the Upgrading of Industrial Structure[J]. Forward Position, 2018.

10. Jie H, Peng-Cheng Z. Empirical Analysis of Financial Development Promoting Industrial Structure Optimization[J]. Journal of Bengbu University, 2018. 